\title{
KEKUASAAN DISKRESI HAKIM PENGADILAN HUBUNGAN INDUSTRIAL
}

\author{
Nindry Sulistya Widiastiani \\ Fakultas Hukum Universitas Atma Jaya Yogyakarta \\ email: nindry.widiastiani@uajy.ac.id
}

disampaikan 17/4/2020 - di-review 21/5/2020 - diterima 31/5/2021

DOI: $10.25123 /$ vej.v7i1.3843

\begin{abstract}
In this article the author discusses the discretionary powers granted to Labour Dispute Court judges. Better known, in comparison, are the discretionary powers of criminal court judges in determining penal sanctions or of Islamic court judges when granting dispensation to marry for underage couples. Using a juridical normative method, the discussion focusses on the principles underlying the Labour Dispute Court judge' discretionary powers and its implementation. The analysis shows that Labour Dispute Court judges do have and enjoy discretionary powers in determining betterment of working conditions, how to best fill gaps or seek clarity in the face of ambiguous rules and regulations found in work contract, company regulations or collective work agreement.
\end{abstract}

Keywords

discretionary powers, Judges, Labour Dispute Court

\begin{abstract}
Abstrak
Tulisan ini menganalisis kewenangan diskresioner hakim di lingkungan Pengadilan Hubungan Industrial. Ini dapat kita bandingkan dengan kewenangan diskresioner hakim yang sudah lebih dikenal dalam lingkungan peradilan pidana, berkenaan dengan penetapan sanksi pidana atau di lingkungan pengadilan agama, berkenaan dengan dispensasi perkawinan. Penelitian yuridis normatif ini menelaah prinsip-prinsip yang mengatur kewenangan diskresioner hakim Pengadilan Hubungna Industrial serta penerapannya. Analisis yang dilakukan menunjukkan bahwa pada hakim Pengadilan Hubungan Industrial diberikan kewenangan diskresioner untuk memutus persoalan peningkatan syarat kerja, ketiadaan atau ketidak-jelasan ketentuan dalam perjanjian kerja, peraturan perusahaan atau perjanjian kerja bersama.
\end{abstract}

Kata Kunci:

Kewenangan diskresioner, Hakim, Pengadilan Hubungan Industrial

\section{Pendahuluan}

Undang-Undang Nomor 13 Tahun 2003 Tentang Ketenagakerjaan (UU Ketenagakerjaan) mengatur mengenai hubungan industrial. Hubungan industrial dalam Pasal 1 angka 16 didefinisikan sebagai:

"suatu sistem hubungan yang terbentuk antara pelaku dalam proses produksi barang dan/atau jasa yang terdiri dari unsur pengusaha, pekerja/buruh dan pemerintah yang berdasarkan pada nilai-nilai Pancasila dan Undang-Undang Dasar Negara Republik Indonesia Tahun 1945 (UUD NRI Tahun 1945)". 
Pada pelaksanaannya, hubungan antara para pelaku hubungan industrial, yakni pekerja, pengusaha dan pemerintah (sebagai aspek aktif negara), terdapat berbagai perbedaan baik dalam hal kepentingan, pandangan dan sebagainya. ${ }^{1}$ Perbedaan-perbedaan tersebut menjadikan hubungan, terutama antara pekerja dengan pengusaha, menjadi rawan timbulnya suatu perselisihan. Oleh karena itu, hukum ketenagakerjaan telah menyediakan sarana penyelesaian perselisihannya, yakni dengan diundangkannya Undang-Undang Nomor 2 Tahun 2004 Tentang Penyelesaian Perselisihan Hubungan Industrial (UU PPHI).

Hadirnya UU PPHI memberikan pedoman mengenai bagaimana cara serta prosedur dalam menyelesaikan perselisihan hubungan industrial. UU PPHI tersebut mengatur bahwa penyelesaian perselisihan hubungan industrial salah satunya dapat dilakukan melalui pengadilan. Pengadilan yang diberikan kewenangan untuk itu yakni Pengadilan Hubungan Industrial. Kehadiran Pengadilan Hubungan Industrial ini merupakan suatu terobosan dalam hukum ketenagakerjaan yang sebelumnya belum pernah menghadirkan kekuasaan yudikatif untuk menyelesaikan perselisihan yang timbul di antara pekerja dan pengusaha.

Sebagaimana lingkungan peradilan lainnya, penyelesaian perselisihan melalui Pengadilan Hubungan Industrial dilakukan oleh hakim, baik hakim karier maupun hakim ad hoc. Tidak berbeda dengan hakim-hakim yang berada di lingkungan peradilan lainnya, hakim di Pengadilan Hubungan Industrial juga dituntut untuk menyelesaikan perselisihan hubungan industrial yang diajukan kepadanya secara adil. Pasal 100 UU PPHI menyebutkan bahwa, "dalam mengambil putusan, majelis hakim mempertimbangkan hukum, perjanjian yang ada, kebiasaan dan keadilan". Penerapan nilai-nilai keadilan dalam setiap putusan penyelesaian perselisihan hubungan industrial menjadi penting untuk diperhatikan. Penyelesaian perselisihan sejatinya hanya dapat dicapai apabila

1 Ari Hernawan, Penyelesaian Sengketa Hubungan Industrial, UII Press, Yogyakarta, 2018, hlm. 31. 
para pihak sungguh merasa mendapatkan keadilan dalam proses penyelesaiannya. $^{2}$

Hal ini sejalan dengan konsepsi hubungan industrial di Indonesia yang dikenal dengan nama Hubungan Industrial Pancasila (HIP). ${ }^{3}$ Hubungan Industrial Pancasila ini menghendaki terciptanya hubungan industrial di Indonesia yang tidak hanya harmonis, tapi juga dinamis dan berkeadilan. ${ }^{4}$ Amanat konsepsi Hubungan Industrial Pancasila ini tentunya diemban pula oleh hakim Pengadilan Hubungan Industrial yang berwenang untuk menyelesaikan perselisihan. Putusan-putusan yang dihasilkan haruslah mengawal kondisi keharmonisan, kedinamisan dan dijiwai oleh nilai-nilai keadilan.

Permasalahannya, kedudukan pekerja dengan pengusaha dalam hubungan kerja seringkali tidak seimbang. Hubungan antara pekerja dengan pengusaha memang diawali dengan adanya suatu perjanjian, yakni perjanjian kerja. Mendasarkan pada keilmuan hukum perdata, para pihak dalam perjanjian semestinya memiliki kedudukan yang setara, namun berbeda halnya dengan hubungan antara pekerja dengan pengusaha. Pekerja dan pengusaha secara yuridis mempunyai kedudukan yang sama di muka hukum (equality before the law), namun secara sosiologis pengusaha menduduki posisi sosial ekonomi yang lebih tinggi dibanding pekerja. ${ }^{5}$ Kedudukan yang sedemikian ini ternyata menimbulkan implikasi yang cukup serius. Posisi tawar (bargaining position) dari pekerja menjadi lebih lemah daripada pengusaha. Melihat kenyataan yang demikian, hakim Pengadilan Hubungan Industrial dituntut tidak hanya harus adil dalam mengambil keputusan, tetapi juga harus sensitif dengan persoalan pekerja, sebagai pihak yang lebih lemah dalam hubungan industrial. ${ }^{6}$

Menurut ajaran Gustav Radburch, suatu putusan hendaknya memuat unsur kepastian hukum (rechtssicherheit), kemanfaatan (zweckmassigkeit), dan juga

Id., hlm. 123.

Abdul Khakim, Pengantar Hukum Ketenagakerjaan Indonesia berdasarkan Undang-Undang Nomor 13 Tahun 2003, Citra Aditya Bhakti, Bandung, 2003, hlm. 50.

4 Id.

5 HP Rajagukguk, Peran Serta Pekerja dalam Pengelolaan Perusahaan (Co-Determination), Fakultas Hukum Universitas Indonesia, Jakarta, 2000, hlm. 3.

6 Supra, no 3. 
keadilan (gerechtigkeit). ${ }^{7}$ Mendasarkan pada ajaran tersebut, terlihat bahwa keadilan merupakan salah satu tujuan utama dari hukum, di samping kemanfaatan dan kepastian hukum. ${ }^{8}$ Pada konteks penyelesaian perselisihan hubungan industrial, hakim harus lebih jeli dalam memeriksa fakta-fakta yang ada karena adanya fakta bahwa kedudukan pekerja seringkali lebih subordinat dari pengusaha. Hakim dalam memutus perkara tidak boleh hanya membatasi diri pada teks perundang-undangan saja, namun juga memperhatikan nurani, akal sehat, kejujuran, sehingga putusan yang dihasilkan mewujudkan keadilan. ${ }^{9}$ Pada posisi yang demikian, hakim Pengadilan Hubungan Industrial dituntut untuk bertindak menggunakan kebijaksanaannya demi memutus perkara secara adil.

Konsep bertindak dengan menggunakan kebebasan dan kebijaksanaan ini dikenal dengan kekuasaan diskresi. Diskresi berasal dari Bahasa Belanda yang kemudian diartikan sebagai wise conduct, individual judgement dan the power of free decision making. ${ }^{10}$ Artinya, seorang pejabat berwenang dalam memutuskan suatu tindakan tidak semata-mata berdasarkan undang-undang, namun atas dasar kebijaksanaan sendiri, pertimbangan atau keadilan. ${ }^{11}$ Dengan kata lain, konsep ini memberikan dasar keleluasaan bagi pihak yang berwenang untuk memutuskan sesuatu sesuai dengan kebijaksanaan dan pertimbangannya sendiri. Konsep diskresi ini mulanya dikenal dalam cabang ilmu hukum administrasi negara.

Menurut ajaran yang saat ini dianut di Indonesia, hakim juga mempunyai kekuasaan diskresi. ${ }^{12}$ Contohnya pada perkara pidana, hakim diberikan keleluasaan untuk menentukan besar dan lamanya pidana atau pada Pengadilan Agama, hakim diberikan keleluasaan untuk menetapkan alasan yang sah atau tidak sah dalam perkara permohonan dispensasi perkawinan. Di sisi lain, Subekti

\footnotetext{
Sudikno Mertokusumo, Mengenal Hukum Suatu Pengantar, Liberty, Yogyakarta, 2003, hlm. 92.

8 Achmad Ali, Menguak Tabir Hukum (Suatu Kajian Filosofis dan Sosiologis, Gunung Agung, Jakarta, 2002, hlm. 72.

9 Bayu Setiawan, Penerapan Hukum Progresif Oleh Hakim Untuk Mewujudkan Keadilan Substantif Transedensi, Kosmik Hukum No 1 Vol 18 Januari 2018, hlm. 177.

10 Bryan A Garner, Black's Law Dictionary Ninth Edition, Thomson Reuters, USA, 2009, hlm. 534.

11 Mhd Taufiqurrahman, Kedudukan Diskresi Pejabat Pemerintahan, Jurnal Retentum No 1 Vol 1 Agustus 2019, hlm. 56.

12 Togi Pangaribuan, Permasalahan Penerapan Klausula Pembatasan Pertanggungjawaban Dalam Perjanjian Terkait Hak Menuntut Ganti Kerugian Akibat Wanprestasi, Jurnal Hukum dan Pembangunan No 2 Vol 49 2019, hlm. 451.
} 
juga menyebutkan bahwa dalam peradilan perdata, khususnya dalam perkara wanprestasi, hakim mempunyai kekuasaan diskresi berupa kebebasan untuk menilai besar kecilnya kelalaian debitur. ${ }^{13}$ Kesemuanya ini dilakukan dalam rangka mewujudkan keadilan dalam setiap putusannya, sehingga hakim diberikan keleluasaan untuk menerapkan pertimbangan sesuai dengan kebijaksanaannya.

Pada praktik penyelesaian perselisihan di Pengadilan Hubungan Industrial, penerapan kekuasaan diskresi ini tentunya juga penting untuk dilakukan. Misalnya, ketika terjadi perselisihan yang timbul akibat pembayaran kompensasi uang pisah atas Pemutusan Hubungan Kerja (PHK). PHK yang dilakukan terhadap pekerja yang mangkir bekerja, oleh Pasal 168 UU Ketenagakerjaan diatur haruslah diberikan kompensasi berupa uang penggantian hak dan uang pisah. Besaran uang pisah telah diatur dalam Pasal 156 ayat (4) UU Ketenagakerjaan, namun untuk uang pisah, UU Ketenagakerjaan mengamanatkan besarannya agar diatur pada perjanjian kerja, peraturan perusahaan, atau perjanjian kerja bersama. Permasalahannya, bagaimana jika kemudian besaran uang pisah ini belum diatur tersendiri dalam perjanjian kerja, peraturan perusahaan, atau perjanjian kerja bersama? Lantas siapa yang kemudian dapat menetapkan besarannya? Di sinilah kemudian akan muncul pentingnya peran hakim untuk menggunakan kekuasaan diskresinya, yakni menetapkan besaran uang pisah yang paling adil untuk pekerja.

Di sisi lain, terdapat kenyataan bahwa posisi pekerja dan pengusaha tidak seimbang. Tidak seperti perkara perdata biasa, perkara hubungan industrial ini diwarnai dengan kesubordinatan posisi tawar pekerja. Misalnya dalam hal terjadi perselisihan kepentingan, sebagaimana diatur dalam UU PPHI, bahwa perselisihan ini muncul karena adanya perubahan syarat-syarat kerja. Pekerja menuntut pengusaha untuk menaikkan upahnya. Pengusaha menolak tanpa alasan yang jelas, serta undangan perundingan yang dilayangkan oleh pekerja diabaikan. Terlihat bahwa pekerja sebenarnya tidak mempunyai bargaining position yang cukup kuat. Jika kemudian perselisihan ini berujung di Pengadilan Hubungan Industrial, peran hakim sangat besar untuk membantu memeriksa dan

13 Subekti, Hukum Perjanjian, Intermasa, Jakarta, 2005, hlm. 50. 
menetapkan apakah tuntutan kenaikan upah tersebut penting untuk dilakukan dan berapa besaran yang layak untuk pekerja sekaligus tidak memberatkan pengusaha. Oleh karena itu, di Pengadilan Hubungan Industrial hakim dituntut untuk bekerja ekstra dalam menyusun pertimbangan dalam putusan untuk mewujudkan keadilan bagi para pihak, terutama pekerja. Penerapan kekuasaan diskresi di Pengadilan Hubungan Industrial akan membuka kemungkinan bagi hakim untuk memutus perkaranya dengan kebijaksanaannya demi mengedepankan keadilan. Lantas, sebenarnya bagaimana peluang penerapan kekuasaan diskresi ini pada penyelesaian perselisihan di Pengadilan Hubungan Industrial? Hal tersebut menarik untuk dibahas lebih lanjut.

Penelitian ini bertujuan untuk menganalisis kemungkinan penerapan kekuasaan diskresi oleh hakim Pengadilan Hubungan Industrial. Selama ini, kekuasaan diskresi lebih banyak dikenal dalam peradilan pidana untuk menentukan sanksi pidana, peradilan agama dalam penetapan dispensasi perkawinan dan peradilan perdata dalam perkara perjanjian. Penelitian ini merupakan penelitian normatif dengan menggunakan pendekatan konseptual (conceptual approach) dan pendekatan perundang-undangan (statute approach).

\section{Pembahasan}

\section{Pengadilan Hubungan Industrial}

UU Ketenagakerjaan pada intinya mengatur mengenai hubungan antara aktor utamanya, yakni pekerja dengan pengusaha. Hubungan antara kedua aktor utama tersebut dikenal dengan hubungan kerja. Pasal 1 angka 15 UU Ketenagakerjaan mencantumkan definisi hubungan kerja sebagai hubungan antara pengusaha dengan pekerja/buruh berdasarkan perjanjian kerja, yang mempunyai unsur pekerjaan, upah dan perintah.

Dilihat dari sudut sejarahnya, hubungan kerja merupakan pengganti dari istilah hubungan perburuhan. Hubungan perburuhan merupakan terjemahan dari istilah labour relation pada permulaan perkembangan pembahasan hubungan 
antara pekerja dengan pengusaha. ${ }^{14}$ Pada perkembangan-perkembangan selanjutnya disadari bahwa hubungan antara pekerja dengan pengusaha bukanlah merupakan persoalan yang berdiri sendiri, melainkan dipengaruhi oleh berbagai faktor, seperti ekonomi, sosial, dan politik. ${ }^{15}$ Sejak saat itu, mulai dikenal istilah industrial relation.

Undang-Undang Ketenagakerjaan akhirnya membedakan istilah antara hubungan kerja dan hubungan industrial. Hubungan industrial dalam Pasal 1 angka 16 didefinisikan sebagai suatu sistem hubungan yang terbentuk antara pelaku dalam proses produksi barang dan/atau jasa yang terdiri dari unsur pengusaha, pekerja/buruh dan pemerintah yang berdasarkan pada nilai-nilai Pancasila dan UUD NRI Tahun 1945. Dari definisi tersebut terlihat bahwa hubungan industrial mempunyai lingkup yang lebih luas. Hal ini disebabkan dengan hadirnya pemerintah sebagai salah satu aktor dalam hubungan tersebut.

Indonesia mempunyai konsepsi sendiri terhadap pelaksanaan hubungan industrialnya dengan menanamkan nilai-nilai ideologi yang ada. Falsafah hubungan industrial yang dianggap sesuai dengan kepribadian bangsa Indonesia kemudian disebut dengan nama Hubungan Industrial Pancasila (HIP). ${ }^{16}$ Konsep Hubungan Industrial Pancasila menghendaki hubungan industrial di Indonesia berjalan dengan harmonis, dinamis, dan berkeadilan.

Pada kenyataannya, sulit untuk menciptakan hubungan industrial yang harmonis, dinamis dan berkeadilan sebagaimana dicita-citakan konsep Hubungan Industrial Pancasila. Terutama dalam konteks hubungan pekerja dengan pengusaha, selalu saja ditemui keadaan-keadaan yang membuat hubungan tersebut menjadi rawan konflik atau perselisihan. Dimulai dari adanya perbedaan kepentingan antara pekerja dengan pengusaha, sampai dengan kenyataan bahwa posisi tawar pekerja berada di tingkat yang lebih subordinat dari pengusaha. Mendasarkan pada kenyataan yang demikian ini, hukum ketenagakerjaan telah

Supra, no 1 , hlm. 1.

Id., hlm. 2.

Supra, no 1, hlm. 14. 
menyiapkan prosedur bagaimana menyelesaikan perselisihan dalam hubungan industrial. Pedoman ini dituangkan dalam UU PPHI.

UU PPHI mengatur terdapat beberapa prosedur atau tahapan penyelesaian perselisihan hubungan industrial. Tahapan-tahapan tersebut tidak boleh dilompati oleh para pihak, atau dengan kata lain para pihak harus melewati satu tahapan demi tahapan secara berurutan. Pertama yakni penyelesaian melalui perundingan bipartit. Kedua, penyelesaian melalui mediasi, konsiliasi atau arbitrase. Ketiga, penyelesaian melalui jalur litigasi, yakni di Pengadilan Hubungan Industrial. Pada pembahasan ini pembicaraan akan difokuskan pada penyelesaian perselisihan hubungan industrial melalui Pengadilan Hubungan Industrial.

UU PPHI dalam Pasal 1 angka 17 mendefinisikan Pengadilan Hubungan Industrial sebagai pengadilan khusus yang dibentuk di lingkungan Pengadilan Negeri yang berwenang memeriksa, mengadili dan memberi putusan terhadap perselisihan hubungan industrial. Pengadilan Hubungan Industrial secara struktural merupakan bagian dari peradilan umum, yakni Pengadilan Negeri, yang menjalankan kewenangan khusus untuk menyelesaikan perselisihan atau sengketa-sengketa yang berkaitan dengan hubungan industrial. Sama halnya dengan lingkungan pengadian lainnya, penyelesaian perselisihan juga ditangani oleh hakim. Hanya saja, selain hakim karier dari Pengadilan Negeri setempat, Pengadilan Hubungan Industrial juga mempunyai hakim ad hoc dari unsur pekerja dan pengusaha. Hakim-hakim inilah yang akan mengawal penyelesaian perselisihan sesuai dengan tujuan Hubungan Industrial Pancasila, yakni harmonis, dinamis dan berkeadilan.

Pasal 56 UU PPHI menyebutkan bahwa Pengadilan Hubungan Industrial bertugas dan berwenang memeriksa dan memutus:

1. di tingkat pertama mengenai perselisihan hak;

2. di tingkat pertama dan terakhir mengenai perselisihan kepentingan;

3. di tingkat pertama mengenai perselisihan pemutusan hubungan kerja;

4. di tingkat pertama dan terkahir mengenai perselisihan antar serikat pekerja/serikat buruh dalam satu perusahaan.

Mendasarkan dari Pasal 56 tersebut, terdapat empat macam perselisihan hubungan industrial yang dapat diselesaikan oleh Pengadilan Hubungan 
Industrial, yakni perselisihan hak, perselisihan kepentingan, perselisihan pemutusan hubungan kerja dan perselisihan antar serikat pekerja/buruh di satu perusahaan. Perselisihan hak merupakan perselisihan yang timbul karena tidak dipenuhinya hak normatif, sementara perselisihan kepentingan merupakan perselisihan yang timbul karena tidak adanya kesesuaian pendapat dalam pembuatan dan/atau perubahan syarat-syarat kerja. ${ }^{17}$

Pengadilan Hubungan Industrial merupakan pengadilan khusus di lingkup Pengadilan Negeri, sehingga hukum acara yang berlaku pada Pengadilan Hubungan Industrial adalah hukum acara yang berlaku pada pengadilan perdata, yakni hukum acara perdata. Hal ini termaktub dalam Pasal 57 UU PPHI. Meski demikian, terdapat beberapa poin pengecualian, yakni hukum acara yang diatur secara khusus oleh UU PPHI yang sedikit berbeda dari hukum acara perdata pada umumnya. Pengecualian-pengecualian itu antara lain ${ }^{18}$ :

1. pengaturan tentang biaya perkara hanya dikenakan pada gugatan yang nilainya di atas $\mathrm{Rp}$ 150.000.000,00;

2. susunan majelis hakim bersifat tripartit yang terdiri dari satu hakim karier Pengadilan Negeri dan dua hakim ad hoc, satu dari unsur pekerja, satu dari unsur pengusaha;

3. gugatan diajukan di tempat pekerja bekerja, bukan mengikuti asas actor sequitur forum rei;

4. dimungkinkannya pengurus serikat pekerja/buruh dan organisasi pengusaha sebagai kuasa hukum dari para pihak;

5. wajib melampirkan risalah perundingan sebelumnya bersama dengan pendaftaran gugatan;

6. terdapat prosedur dismissal, yakni hakim berkewajiban untuk memeriksa isi gugatan, jika terdapat kekurangan hakim meminta Penggugat untuk menyempurnakan;

7. tenggang waktu putusan harus dijatuhkan paling lama 50 hari sejak sidang pertama;

8. apabila terdapat perselisihan yang bersamaan antara perselisihan pemutusan hubungan kerja dengan perselisihan hak atau kepentingan, maka hakim wajib memutus perselisihan hak atau kepentingan terlebih dahulu.

17 Undang-Undang R.I., No. 2 Tahun 2004, Penyelesaian Perselisihan Hubungan Industrial, L.N.R.I. Tahun 2004 No. 6, Pasal 1 angka 2 dan 3.

18 Khairani, Sulitnya Melaksanakan Putusan Pengadilan Hubungan Industrial (Studi Kasus Putusan Mahkamah Agung No 178 K/Pdt.Sus-PHI/2015, Prosiding Konferensi Ke-2 Perkumpulan Pengajar dan Praktisi Hukum Ketenagakerjaan Indonesia (P3HKI), Medan, Oktober 2017, hlm.345. 


\section{Kekuasaan Diskresi}

Istilah diskresi berasal dari bahasa Belanda (discretionair) yang artinya kebijaksanaan, atau dalam bahasa Inggris disebut modesty, considerateness, yaitu dalam halnya memutuskan sesuatu tidak berdasarkan ketentuan peraturan, undang-undang atau hukum yang berlaku, namun atas dasar kebijaksanaan, pertimbangan dan keadilan. ${ }^{19}$ S. Prajudi Atmosudirjo dalam bukunya juga menyinggung mengenai berbagai macam istilah diskresi dalam beberapa bahasa, yakni discretionnaire (Perancis), freies ermessen (Jerman), dan discretion (Inggris). ${ }^{20}$ Diskresi, yang artinya menurut kebijaksanaan, dan sebagai kata sifat, diartikan sebagai "menurut wewenang atau kekuasaan yang tidak atau tidak seluruhnya terikat pada undang-undang".21

Teori mengenai diskresi ini pada mulanya digunakan sebagai salah satu teori utama di cabang ilmu hukum administrasi negara. Keberadaan teori diskresi ini diterapkan dalam kaitannya pelaksanaan pemerintahan. Diskresi (discretion) secara bahasa merupakan kebijaksanaan, keleluasaan, penilaian, kebebasan untuk menentukan. ${ }^{22}$ Thomas J Aaron mendefinisikan diskresi "discretion is power authority coffered by law to action on the basic judgement of conscience, and its use is more than idea of morals than law", yang diartikan sebagai suatu kekuasaan atau wewenang yang dilakukan berdasarkan hukum atas pertimbangan dan kenyataan serta lebih menekankan pertimbangan-pertimbangan moral daripada pertimbangan hukum. ${ }^{23}$

Melihat dari definisi tersebut, diskresi merupakan teori dalam pelaksanaan pemerintahan yang memungkinkan untuk seorang pejabat yang berwenang untuk mendapatkan kebebasan dalam mengambil tindakan sesuai dengan kebijaksanaannya dan pertimbangannya sendiri. Istilah diskresi bahkan dapat

Yan Pramadya Puspa, Kamus Hukum, Aneka Ilmu, Semarang, 2004, hlm. 319.

S. Prajudi Atmosudirjo, Hukum Administrasi Negara, Ghalia Indonesia, Bogor, 1994, hlm. 82.

Supra, no 9, hlm. 51.

22 Arief Sultony, Diskresi Dalam Penentuan Hasil Pemeriksaan Pajak Untuk Ditindaklanjuti Penegakan Hukum Pidana di Bidang Perpajakan, Simposium Keuangan Negara, Jakarta, 2018, hlm. 479 .

23 M Faal, Penyaringan Perkara Pidana Oleh Polisi (Diskresi Kepolisian), Pradnya Paramita, Jakarta, 1991, hlm. 16. 
ditemukan dalam peraturan perundang-undangan Indonesia yakni dalam UndangUndang Nomor 30 Tahun 2014 Tentang Administrasi Pemerintahan. Pasal 1 angka 9 menyebutkan,

"diskresi adalah keputusan dan/atau tindakan yang ditetapkan dan/atau dilakukan oleh pejabat pemerintahan untuk mengatasi persoalan konkret yang dihadapi dalam penyelenggaraan pemerintahan dalam hal peraturan perundang-undangan tidak memberikan pilihan, tidak mengatur, tidak lengkap atau tidak jelas, dan/atau adanya stagnasi pemerintahan".

Indroharto menyebut diskresi sebagai wewenang fakultatif, yakni wewenang yang tidak mewajibkan pejabat yang berwenang untuk tidak melaksanakan wewenangnya. ${ }^{24}$ Inilah tadi yang diartikan sebagai kebebasan atau keleluasaan, yakni ketika terjadi peristiwa-peristiwa tertentu yang terkait dengan wewenangnya, pejabat yang bersangkutan mempunyai kebebasan atau keleluasaan untuk menentukan sendiri tindakan apa yang akan diambil terhadap peristiwa yang bersangkutan. Diskresi digunakan untuk memberikan ruang gerak kebebasan kepada pejabat untuk menentukan sendiri, bagaimana mengartikan (menangkap maksud dan tujuan) dari kekuasaan, dan menentukan sendiri apakah ia akan melaksanakan kekuasaannya itu, serta dapat menentukan sendiri kapan ia akan berbuat demikian dan bagaimana caranya menggunakan kekuasaan itu. ${ }^{25}$ Meski begitu, kebebasan melakukan diskresi ini hanya dapat dilakukan dalam hal sesuai dengan kewenangan pejabat yang bersangkutan, tidak bertentangan dengan peraturan perundang-undangan dan asas-asas umum pemerintahan yang baik, serta diambil berdasarkan alasan-alasan yang obyektif.

Diskresi diperlukan sebagai pelengkap asas legalitas bahwa setiap tindakan atau perbuatan administrasi negara harus berdasarkan ketentuan undang-undang, akan tetapi tidak mungkin bagi undang-undang untuk mengatur

24 Indroharto, Usaha Memahami Undang-Undang Tentang Peradilan Tata Usaha Negara: Buku I, Sinar Harapan, Jakarta, 1993, hlm. 99-101.

25 Agus Budi Susilo, Makna dan Kriteria Diskresi Keputusan dan/atau Tindakan Pejabat Pemerintah Dalam Mewujudkan Tata Pemerintahan Yang Baik, Jurnal Hukum dan Peradilan No 1 Vol 4 2015, hlm. 144. 
segala praktik kehidupan sehari-hari. ${ }^{26}$ Dengan kata lain, menurut LaFave, dalam penegakan hukum, diskresi itu penting karena ${ }^{27}$ :

1. tidak ada perundang-undangan yang sedemikian lengkapnya, sehingga dapat mengatur semua perilaku manusia;

2. adanya kasus-kasus individual yang memerlukan penanganan secara khusus.

Mendasarkan pada ajaran-ajaran tersebut, diskresi diarahkan sebagai pilihan tindakan yang dapat diambil oleh pejabat yang berwenang ketika terjadi peristiwa-peristiwa yang tidak diatur oleh peraturan perundangan, atau ketika peraturannya tidak jelas mengatur ataupun ketika terjadi peristiwa khusus lainnya. Kebebasan bertindak dalam diskresi memberikan dasar bagi pejabat yang berwenang untuk bertindak dengan mempertimbangkan sisi lain dari tujuan hukum, yakni kemanfaatan dan keadilan. Tindakan tersebut diambil atas kebijaksanaan dan kearifan pejabat yang berwenang itu sendiri. Oleh karena itu, LaFave menyatakan bahwa hakikatnya diskresi berada di antara hukum dan moral (etika dalam arti sempit). ${ }^{28}$

Menurut ajaran yang saat ini dianut di Indonesia, hakim juga mempunyai kekuasaan diskresi. ${ }^{29}$ Timbulnya praktik penerapan kekuasaan diskresi dalam lingkup peradilan didasari dengan adanya pergeseran pandangan bahwa hakim adalah la boche de la loi, atau hakim adalah corong undang-undang. Pandangan yang meyakini hakim adalah corong undang-undang yang tugasnya hanya menerapkan undang-undang semata dianggap sudah tidak relevan lagi dalam praktik. Di samping kepastian hukum, tujuan hukum ialah untuk memberikan kemanfaatan dan keadilan. Penerapan kekuasaan diskresi dalam praktik peradilan dianggap lebih memberikan keadilan substantif bagi pihak-pihak terkait.

Contoh paling sederhana penggunaan kekuasaan diskresi yakni pertama pada peradilan pidana. Pada proses peradilan pidana hakim mempunyai kebebasan dan keleluasaan untuk menetapkan hukuman bagi terdakwa sesuai

26 Supra, no 20, hlm. 480.

27 Wayne R. LaFave, The Decision To Take A Suspect Into Custody, Little Brown and Company, Boston, 1964, hlm. 15.

28 Id., hlm. 4.

29 Supra, no 10. 
dengan pertimbangan dan kebijaksanaannya. Tentu saja, peraturan perundangundangan tidak semata-mata ditinggalkan, namun menjadi pedoman secara garis besar saja. Terlebih, berkembang trend pada kasus-kasus tindak pidana korupsi, apabila terpidana kasus korupsi mengajukan upaya hukum, maka hukumannya akan diperberat oleh hakim yang bersangkutan. Misalnya pada kasus Angelina Patricia Pinkan Sondakh yang diputus pidana 4 tahun 6 bulan penjara, namun pada tingkat kasasi justru diperberat menjadi 12 tahun penjara. ${ }^{30}$

Contoh kedua, kekuasaan diskresi terlihat pula pada lingkup pengadilan agama dan pengadilan negeri dalam rangka penetapan dispensasi perkawinan. Pada dasarnya, Undang-Undang Nomor 1 Tahun 1974 Tentang Perkawinan juncto Undang-Undang Nomor 16 Tahun 2019 Tentang Perubahan Undang-Undang Perkawinan telah menetapkan bahwa usia minimal untuk diselenggarakannya perkawinan adalah 19 tahun. Apabila para pihak belum mencapai usia 19 tahun, maka perkawinan hanya dapat terselenggara setelah mendapatkan dispensasi dari pengadilan. Permasalahannya, peraturan perundang-undangan tidak memberikan kriteria khusus alasan atau dasar pertimbangan bagi hakim untuk menerima ataupun menolak permohonan dispensasi perkawinan tersebut. ${ }^{31}$ Akibatnya, pada praktiknya hakim dalam memutus dispensasi perkawinan ini menerapkan kekuasaan diskresi, yakni diserahkan kepada kebijaksanaan dan pertimbangan hakim masing-masing.

Contoh ketiga, dalam perkara terkait perjanjian, yakni pembatalan perjanjian misalnya, hakim memiliki kekuasaan untuk menilai besar kecilnya kelalaian debitur dibandingkan dengan berat akibat pembatalan perjanjian yang mungkin menimpa debitur itu. ${ }^{32}$ Jika hakim menimbang kelalaian itu terlalu sepele sedangkan pembatalan perjanjian akan membawa kerugian yang terlalu besar kepada debitur, maka permohonan untuk membatalkan perjanjian ditolak

\footnotetext{
30 Agus Nurudin, Diskresi Yudisial: Antara Keadilan dan Pencitraan, Masalah-Masalah Hukum No 1 Jilid 45 Januari 2016, hlm. 18.

31 Ramadhita, Diskresi Hakim: Pola Penyelesaian Kasus Dispensasi Perkawinan, de Jure: Jurnal Syari'ah dan Hukum No 1 Vol 6 Juni 2014, hlm. 68.

32 Supra, no 10.
} 
oleh hakim. ${ }^{33}$ Demikian pula dalam perkara penuntutan ganti kerugian, hakim berhak menilai pelanggaran perjanjian yang terjadi dan berapa jumlah ganti rugi yang pantas untuk ditetapkan.

Masih dalam pembahasan dalam lingkup peradilan perdata, terdapat putusan yang terkenal mengenai sengketa ganti rugi pembebasan tanah bagi Waduk Kedung Ombo Jawa Tengah. Pada gugatannya masyarakat menuntut nominal ganti rugi pembebasan tanah sebesar Rp 10.000,00 per meter yang berujung ditolak oleh Pengadilan Negeri Semarang dan Pengadilan Tinggi Semarang. Pada tingkat kasasi, melalui putusan Nomor 2263.K/Pdt/1991, hakim justru memutus ganti rugi sebesar Rp 50.000,00 per meter disertai dengan ganti rugi immateriil sebesar Rp 2.000.000.000,00. ${ }^{34}$ Putusan ini disebut-sebut sebagai bentuk sempurna contoh penerapan kekuasaan diskresi dalam praktik peradilan, karena pada kasus tersebut hakim memutus jumlah ganti rugi jauh lebih besar dari yang dituntutkan Penggugat dan ditambah mengabulkan ganti rugi immaterial yang jarang dikabulkan oleh hakim lainnya. Pada pertimbangannya, hakim menyebutkan bahwa putusan tersebut berangkat dari petitum Penggugat yang menyebutkan ex aquo et bono (mohon putusan yang seadil-adilnya). Atas dasar itu, hakim menggunakan kebijaksanaannya untuk mencapai keadilan yang dianggap pantas bagi kasus tersebut.

Dalam konteks kewenangan hakim pada saat mengadili suatu perkara, kekuasaan diskresi merupakan bentuk kebebasan hakim dalam menentukan sikap dan kebijakan, kebebasan untuk memilih, kebebasan untuk mengambil tindakan terhadap suatu masalah yang sedang ditangani. ${ }^{35}$ Manakala terjadi masalah yang penyelesaiannya diserahkan pengadilan, maka hakim memiliki kewenangan untuk mengadili perkara sesuai dengan kepatutan dan keadilan, dan ketentuan dalam undang-undang hanya dijadikan patokan garis besarnya saja. Ajaran hakim yang mempunyai kekuasaan diskresi tersebut selaras dengan amanat Pasal 5 ayat (1)

\footnotetext{
33 Supra, no 11.

34 Bambang Sutiyoso, Mencari Format Ideal Keadilan Putusan dalam Peradilan, Jurnal Hukum No 2 Vol 17 April 2010, hlm. 228.

35 Dina Natalia Kumampung, Tugas Fungsi dan Diskresi Hakim Untuk Mengadili dan Memutus Perkara Pidana, Lex Administratum No 2 Vol VI 2018, hlm. 6.
} 
Undang-Undang Nomor 48 Tahun 2009 Tentang Kekuasaan Kehakiman, merupakan suatu ketentuan mendasar bahwa hakim wajib menggali, mengikuti dan memahami nilai-nilai hukum dan rasa keadilan yang hidup dalam masyarakat. ${ }^{36}$ Surat Keputusan Bersama Ketua Mahkamah Agung RI Nomor 047/KMA/SKB/IV/2009 dan Ketua Komisi Yudisial RI 02/SKB/P.KY/IV/2009 juga mengatur bahwa pada setiap putusan yang dibuat bukan saja berdasarkan peraturan perundang-undangan, tetapi juga rasa keadilan dan kearifan dalam masyarakat. Untuk mencapai keadilan dan kearifan dalam masyarakat, hakim menerapkan kekuasaan diskresi dalam pemeriksaan perkara dalam batas-batas kewenangannya secara ex officio.

\section{Kekuasaan Diskresi Hakim Pengadilan Hubungan Industrial}

Kekuasaan diskresi pada intinya merupakan kekuasaan yang memberikan keleluasaan atau kebebasan bagi pejabat yang berwenang untuk mengambil tindakan sesuai dengan kebijaksanaannya dan pertimbangannya. Dalam konteks hakim di pengadilan, kekuasaan diskresi merupakan kekuasaan yang yang memungkinkan hakim untuk memutus suatu perkara menurut kebijaksanaan dan pertimbangannya sendiri. Penggunaan kekuasaan diskresi ini ditujukan sematamata untuk memenuhi nilai-nilai keadilan dalam setiap putusan hakim. Sebagaimana diketahui, keadilan merupakan salah satu tujuan utama dari hukum, di samping kemanfaatan dan kepastian hukum. ${ }^{37}$ Tujuan hukum itu adalah terciptanya rasa keadilan, maka hukum tanpa keadilan akan sia-sia sehingga hukum tidak lagi berharga di hadapan masyarakat. ${ }^{38}$

Penggunaan kekuasaan diskresi berarti dalam pemeriksaan dan penjatuhan putusannya, hakim menggunaan kebijaksanaannya yang tidak hanya berpegang pada rasionalitas semata, namun juga pada aspek moralitas. Putusan hakim yang lahir dari hasil kontemplasi moral baik dari segi lahiriah maupun batiniah akan menghasilkan putusan hakim yang adil, karena putusan hakim yang berbasis moral tentu saja telah koheren dengan pertimbangan fakta, norma,

\footnotetext{
Supra, no 10.

Supra, no 6.

38 Lon L Fuller, Morality of Law, Yale University Press, New Haven, 1954, hlm. 96.
} 
doktrin baik dari segi lahiriah maupun batiniah, serta lebih komprehensif dan utuh. ${ }^{39}$

Pada konteks hakim di Pengadilan Hubungan Industrial, yang mana menangani perkara penyelesaian perselisihan hubungan industrial antara pekerja dan pengusaha, penggunaan kekuasaan diskresi ini sangat penting untuk dilakukan. Sebagaimana telah disinggung dalam bagian-bagian sebelumnya, posisi tawar pekerja dalam hubungan tersebut seringkali subordinat, sehingga penegakan hukum yang berbasis pada keadilan sangatlah dibutuhkan dalam praktik di Pengadilan Hubungan Industrial. Secara sosiologis dan ekonomis, posisi pekerja lebih lemah dari pada pengusaha. Rawls mengemukakan bahwa ketidaksamaan di bidang sosial ekonomi harus diatur sedemikian rupa agar golongan yang paling lemah atau pihak yang kurang mendapatkan kesempatan atau pihak yang mendapat kesulitan menjadi diuntungkan, diberi kesempatan yang lebih tinggi dan diringankan. ${ }^{40}$ Mendasarkan pada teori keadilan Rawls ini, pekerja perlu mendapat jaminan keseimbangan dan keadilan atas hubungannya dengan pengusaha. Penerapan kekuasaan diskresi oleh hakim Pengadilan Hubungan Industrial akan sejalan dengan prinsip-prinsip dalam teori keadilan ini.

Terlebih lagi, amanat dari konsepsi dasar Hubungan Industrial yang menginginkan terwujudnya hubungan industrial di Indonesia yang harmonis, dinamis dan berkeadilan juga sejalan dengan penerapan kekuasaan diskresi ini. Hakim Pengadilan Hubungan Industrial sebagai pihak dari lembaga yang berwenang untuk menyelesaikan perselisihan hubungan industrial juga mempunyai tanggung jawab untuk ikut serta dalam usaha perwujudan hubungan industrial yang berkeadilan. Oleh karena itu, peluang bagi penerapan kekuasaan diskresi di Pengadilan Hubungan Industrial terbuka lebar sebagai manifestasi nilai-nilai keadilan untuk melindungi pekerja.

Peraturan perundang-undangan bidang ketenagakerjaan pada dasarnya digunakan sebagai jaring pengaman (safety net). Diundangkannya peraturan

39 HM. Soerya Respationo dan M Guntur Hamzah, Putusan Hakim: Menuju Rasionalitas Hukum Refleksif Dalam Penegakan Hukum, Jurnal Yustisia No 2 Vol 2 2013, hlm. 104.

40 John Rawls, A Theory of Justice, Massachusetts, The Belknap Press of Harvard University Press, 1971, hlm. 302. 
perundang-undangan bidang ketenagakerjaan semata-mata digunakan untuk menjalankan fungsi negara dalam hubungan industrial, yakni melindungi pihak yang lebih lemah. Hal ini yang mendasari pengaturan dalam peraturan perundang-undangan tersebut hanya bersifat garis besarnya saja. Teknis aturan main yang lebih jelas dan mendetail diserahkan kepada pekerja dan pengusaha untuk diatur ataupun disepakati lebih lanjut. Oleh karenanya, terdapat instrumen aturan lain selain peraturan perundang-undangan, yakni perjanjian kerja, Peraturan Perusahaan (PP) dan Perjanjian Kerja Bersama (PKB). Gunanya adalah sebagai alat untuk menentukan lebih lanjut mengenai aturan main hubungan kerja di masing-masing internal perusahaan.

Bahkan, jika kita membedah peraturan perundang-undangan bidang ketenagakerjaan, terdapat banyak pasal yang secara eksplisit memerintahkan bahwa pekerja dan pengusaha untuk mengatur atau menyepakati lebih lanjut mengenai aturan yang telah ada. Berikut beberapa contoh pasal-pasal dalam UU Ketenagakerjaan dan Undang-Undang Nomor 21 Tahun 2000 Tentang Serikat Pekerja/Serikat Buruh (UU SP/SB) yang secara eksplisit memerintahkan pengaturan lebih lanjut kepada pekerja dan pengusaha:

Tabel 1: Daftar Pasal-Pasal dalam UU Ketenagakerjaan dan UU SP/SB yang memerintahkan pengaturan lebih lanjut dalam perjanjian kerja, $\mathrm{PP}$, dan PKB.

\begin{tabular}{|c|c|c|}
\hline No & Pasal & Uraian \\
\hline 1. & $\begin{array}{l}\text { Pasal } 15 \text { UU SP/SB } \\
\text { beserta } \\
\text { Penjelasannya }\end{array}$ & $\begin{array}{l}\text { Pekerja/buruh yang menduduki jabatan tertentu didalam satu } \\
\text { perusahaan dan jabatan itu menimbulkan pertentangan } \\
\text { kepentingan antara pihak pengusaha dan pekerja/buruh, tidak } \\
\text { boleh menjadi pengurus serikat pekerja/serikat buruh di } \\
\text { perusahaan yang bersangkutan. }\end{array}$ \\
\hline & & $\begin{array}{l}\text { Penjelasan: } \\
\text { Jabatan tertentu yang dimaksud dalam pasal ini, misalnya manager } \\
\text { sumber daya manusia, manager keuangan, manager personalia } \\
\text { sebagaimana yang disepakati dalam PKB. }\end{array}$ \\
\hline 2. & Pasal 29 UU SP/SB & $\begin{array}{l}\text { (1) Pengusaha harus memberi kesempatan kepada pengurus } \\
\text { dan/atau anggota SP/SB untuk menjalankan kegiatan SP/SB } \\
\text { dalam jam kerja yang disepakati oleh kedua belah pihak } \\
\text { dan/atau yang diatur dalam PKB. } \\
\text { (2) Dalam kesepakatan kedua belah pihak dan/atau PKB } \\
\text { sebagaimana dimaksud dalam ayat (1) harus diatur } \\
\text { mengenai: } \\
\text { a. Jenis kegiatan yang diberikan kesempatan; }\end{array}$ \\
\hline
\end{tabular}


b. Tata cara pemberian kesempatan;

c. Pemberian kesempatan yang mendapat upah dan yang tidak mendapat upah.

3. Pasal 79 (3) UU Pelaksanaan waktu istirahat tahunan sebagaimana dimaksud Ketenagakerjaan dalam ayat (2) huruf c diatur dalam perjanjian kerja, PP atau PKB.

4. Pasal 81 UU (1) Pekerja/buruh perempuan yang dalam masa haid merasakan Ketenagakerjaan sakit dan memberitahukan kepada pengusaha, tidak wajib bekerja pada hari pertama dan kedua pada waktu haid.

(2) Pelaksanaan ketentuan sebagaimana dimaksud dalam ayat (1) diatur dalam perjanjian kerja, PP atau PKB.

5. Pasal 83 UU Pekerja/buruh perempuan yang anaknya masih menyusui harus Ketenagakerjaan beserta Penjelasannya diberi kesempatan sepatutnya untuk menyusui anaknya jika hal itu harus dilakukan selama waktu kerja

\section{Penjelasan:}

Yang dimaksud dengan kesempatan sepatutnya dalam pasal ini adalah lamanya waktunya yang diberikan kepada pekerja/buruh perempuan untuk menyusui bayinya dengan memperhatikan tersedianya tempat yang sesuai dengan kondisi dan kemampuan perusahaan, yang diatur dalam PP atau PKB.

\begin{tabular}{|c|c|c|}
\hline & $\begin{array}{l}\text { Pasal } 93 \text { ayat (5) } \\
\text { Ketenagakerjaan }\end{array}$ & $\begin{array}{l}\text { Pengaturan pelaksanaan ketentuan sebagaimana dimaksud dalam } \\
\text { ayat (2) ditetapkan dalam perjanjian kerja, PP atau PKB. }\end{array}$ \\
\hline 7. & $\begin{array}{l}\text { Pasal } 154 \text { huruf c UU } \\
\text { Ketenagakerjaan }\end{array}$ & $\begin{array}{l}\text { Penetapan sebagaimana dimaksud dalam Pasal } 151 \text { ayat (3) tidak } \\
\text { diperlukan dalam hal pekerja/ buruh mencapai usia pensiun } \\
\text { sesuai dengan ketetapan dalam perjanjian kerja, PP, PKB atau } \\
\text { peraturan perundang-undangan. }\end{array}$ \\
\hline 8. & $\begin{array}{l}\text { Pasal } 160 \text { ayat (1) UU } \\
\text { Ketenagakerjaan } \\
\text { beserta } \\
\text { Penjelasannya }\end{array}$ & $\begin{array}{l}\text { Dalam hal pekerja/buruh ditahan pihak yang berwajib karena } \\
\text { diduga melakukan tindak pidana maka pengusaha tidak wajib } \\
\text { membayar upah tetapi wajib memberikan bantuan kepada } \\
\text { keluarga pekerja/buruh yang menjadi tanggungannya. }\end{array}$ \\
\hline & & $\begin{array}{l}\text { Penjelasan: } \\
\text { Keluarga pekerja/buruh yang menjadi tanggungan adalah } \\
\text { istri/suami, anak atau orang tua yang sah menjadi tanggungan } \\
\text { pekerja/buruh berdasarkan perjanjian kerja, PP atau PKB. }\end{array}$ \\
\hline 9. & $\begin{array}{lcc}\text { Pasal } & 162 & \text { UU } \\
\text { Ketenagakerjaan } & \end{array}$ & $\begin{array}{l}\text { Bagi pekerja/buruh yang mengundurkan diri atas kemauan sendiri } \\
\text { yang tugas dan fungsinya tidak mewakili kepentingan pengusaha } \\
\text { secara langsung, selain menerima uang penggantian hak sesuai } \\
\text { ketentuan pasal } 156 \text { ayat (4) diberikan uang pisah yang besarnya } \\
\text { dan pelaksanaannya diatur dalam perjanjian kerja, PP atau } \\
\text { PKB. }\end{array}$ \\
\hline 10. & $\begin{array}{lcc}\text { Pasal } & 168 & \text { UU } \\
\text { Ketenagakerjaan } & \end{array}$ & $\begin{array}{l}\text { (1) Pekerja/buruh yang mangkir selama } 5 \text { (lima) hari kerja atau } \\
\text { lebih berturut-turut tanpa keterangan secara tertulis yang } \\
\text { dilengkapi dengan bukti sah dan telah dipanggil oleh } \\
\text { pengusaha } 2 \text { (dua) kali secara patut dan tertulis dapat diputus } \\
\text { hubungan kerjanya karena dikualifikasikan mengundurkan } \\
\text { diri. } \\
\text { (2) PHK sebagaimana dimaksud dalam ayat (1) pekerja/buruh } \\
\text { yang bersangkutan berhak menerima uang penggantian hak } \\
\text { sesuai ketentuan pasal } 156 \text { ayat (4) dan diberikan uang pisah } \\
\text { yang besarnya dan pelaksanaannya diatur dalam } \\
\text { perjanjian kerja, PP atau PKB. }\end{array}$ \\
\hline
\end{tabular}

Sumber: diolah penulis dari UU Ketenagakerjaan dan UU SP/SB 
Sepuluh pasal di atas merupakan contoh pasal-pasal yang secara gamblang memerintahkan pekerja dan pengusaha untuk menyepakati atau mengatur teknis aturan lebih lanjut dalam PKB atau PP. Hanya saja, meskipun sudah diperintahkan secara eksplisit seperti itu, pada praktiknya masih saja ditemui kelalaian para pihak untuk mengatur lebih lanjut mengenai hal-hal tersebut. Lalu jika ketiadaan aturan tersebut kemudian menimbulkan perselisihan, lantas bagaimana penyelesaiannya? Di sinilah muncul peluang hakim Pengadilan Hubungan Industrial untuk menerapkan kekuasaan diskresi.

Misalnya, dalam Pasal 29 UU SP/SB menyebutkan bahwa:

"pengusaha harus memberikan kesempatan bagi pengurus serikat pekerja untuk melaksanakan tugas atau urusan serikat pekerjanya pada jam kerja dengan jaminan upahnya tetap dibayar".

Hanya saja, pasal tersebut kemudian memerintahkan pekerja dan pengusaha untuk menyepakati lebih lanjut dalam PKB kegiatan-kegiatan seperti apa yang dibolehkan untuk dilakukan pengurus serikat pekerja pada waktu jam kerja. Pada praktiknya, masih banyak PKB perusahaan yang tidak mengatur lebih lanjut mengenai persoalan ini. Sebagai ilustrasi contoh, terdapat pengurus serikat pekerja yang menyelenggarakan rapat serikat ketika jam kerja masih berlangsung. Pengusaha merasa dirugikan terhadap kegiatan tersebut lalu memberikan sanksi kepada pekerja tersebut. Pekerja kemudian merasa haknya dilanggar karena berpedoman pada Pasal 29 ini. Walaupun demikian, pengusaha dan pekerja sendiri belum mengatur mana kegiatan serikat yang boleh dilakukan pada jam kerja dan mana yang tidak boleh. Jika permasalahan ini berkembang menjadi perselisihan di pengadilan, siapa lagi yang punya kewenangan untuk menetapkan kegiatan mana yang boleh dan mana yang tidak boleh, jika bukan hakim Pengadilan Hubungan Industrial? Di sinilah peluang kekuasaan diskresi dapat diterapkan. Hakim Pengadilan Hubungan Industrial dapat menggunakan kebebasannya untuk menetapkan apakah kegiatan yang disengketakan tersebut boleh dilakukan saat jam kerja ataukah tidak. Hakim diberikan kesempatan untuk menggunakan kebijaksanaannya dan pertimbangannya dalam menciptakan putusan yang adil bagi para pihak. 
Ilustrasi lainnya, yakni terkait penetapan besaran uang pisah bagi pekerja yang mengundurkan diri dalam Pasal 162 UU Ketenagakerjaan. Pasal tersebut secara gamblang mengatur bahwa besaran uang pisah yang wajib diberikan oleh pengusaha kepada pekerja yang mengundurkan diri harus diatur dalam PP maupun PKB. Pada faktanya masih juga ditemui perusahaan yang belum mengatur mengenai hal tersebut. Saat terdapat pekerja yang mengundurkan diri lalu menuntut uang pisah, hal ini juga dapat menimbulkan perselisihan. Misalnya pengusaha sudah memberikan uang pisahnya, namun pekerja merasa nominal tersebut masih kurang, yang kemudian terjadi perselisihan yang di bawa hingga tingkat pengadilan. Maka hakim Pengadilan Hubungan Industrial punya peluang untuk menetapkan besaran uang pisah menggunakan kekuasaan diskresinya. Hal ini disebabkan para pihak sendiri belum mengatur besarannya sesuai dengan apa yang telah diamanatkan undang-undang. Hakim dapat menggunakan kebijaksanaannya dan rasionalitasnya untuk menetapkan besaran uang pisah yang adil bagi pekerja dan disesuaikan dengan kemampuan perusahaan pula.

Peraturan perundang-undangan bidang ketenagakerjaan yang bersifat sebagai jaring pengaman (safety net), selain hanya mengatur garis besarnya saja, juga hanya mengatur mengenai hak-hak minimal yang harus diberikan kepada pekerja. Secara filosofis, kehadiran peraturan perundang-undangan bidang ketenagakerjaan diperuntukkan untuk melindungi agar para pekerja tidak diberikan hak-hak di bawah apa yang sudah ditetapkan dalam undang-undang. Misalnya mengenai cuti tahunan yang diatur wajib diberikan kepada pekerja selama 12 hari setiap tahunnya. Aturan ini merupakan prasyarat minimal, dengan kata lain, terdapat kemungkinan untuk diatur lebih baik dalam PP maupun PKB. Pengusaha dan pekerja boleh menyepakati atau mengatur hari cuti tahunan yang lebih banyak dari aturan minimal 12 hari tersebut.

Pengaturan yang lebih baik mengenai cuti tahunan tersebut merupakan bentuk dari peningkatan atau perubahan syarat-syarat kerja. Peningkatan dan perubahan syarat-syarat kerja tersebut pada praktiknya juga tak luput menjadi sumber perselisihan di antara pekerja dan pengusaha. Kadangkala tuntutan peningkatan syarat kerja yang diajukan oleh pekerja ditolak oleh pengusaha 
sehingga tercetuslah perselisihan. Perselisihan mengenai peningkatan atau perubahan syarat kerja ini disebut oleh UU PPHI sebagai perselisihan kepentingan. Apabila kemudian perselisihan kepentingan tersebut sampai ke tingkat pengadilan, terbuka kemungkinan lagi bagi hakim Pengadilan Hubungan Industrial untuk menerapkan kekuasaan diskresi. Hakim mempunyai keleluasaan untuk mempertimbangkan dan menetapkan apakah peningkatan syarat kerja yang dituntutkan oleh pekerja itu dapat dikabulkan atau tidak. Penilaian tersebut diserahkan kepada kebijaksanaan dan rasionalitas hakim Pengadilan Hubungan Industrial.

Kemungkinan lainnya dalam rangka penerapan kekuasaan diskresi di Pengadilan Hubungan Industrial ialah tidak lain timbul ketika terdapat perkara yang mengharuskan hakim untuk melindungi pekerja sebagai pihak yang mempunyai posisi tawar lebih lemah. Misalnya, ketika pekerja dituntut oleh pengusaha untuk membayar penalti atas pengunduran dirinya yang nilainya sedemikian besarnya. Nominal penalti yang dibebankan kepada pekerja tersebut sedemikian besarnya sehingga tidak mungkin bagi pekerja untuk dapat melunasinya. Jika kemudian tuntutan ini berkembang menjadi suatu perselisihan di pengadilan, terbuka kembali peluang hakim untuk menerapkan kekuasaan diskresi. Hakim dapat menggunakan kebijaksanaannya dan rasionalitasnya untuk menetapkan besaran penalti yang adil dan sesuai dengan keadaan pekerja. Hal ini didasari atas posisi tawar pekerja yang lebih lemah sehingga ketika terjadi perjanjian kerja standar yang memuat klausul penalti tersebut pekerja hanya mempunyai dua pilihan take it or leave it. Kehadiran hakim Pengadilan Hubungan Industrial dalam perkara macam inilah menjadi sangat penting demi melindungi pekerja dari ketidakadilan sebagaimana dikemukakan dalam teori keadilan Rawls yang telah disinggung sebelumnya.

Mendasarkan pada pembahasan di atas, terlihat bahwa sebenarnya di lingkungan Pengadilan Hubungan Industrial juga terbuka kemungkinan bagi hakim untuk menerapkan kekuasaan diskresi. Peluang penerapan kekuasaan diskresi bagi hakim Pengadilan Hubungan Industrial terbuka sedemikian lebarnya karena sifat perkaranya sendiri memang memungkinkan untuk diterapkan 
kekuasaan diskresi. Perselisihan dalam hubungan industrial tidak selalu berangkat dan peraturan perundang-undangan dan perjanjian, kadangkala berupa perselisihan kepentingan yang berupa tuntutan peningkatan syarat-syarat kerja yang sudah ditetapkan. Selain itu, perselisihan yang terjadi juga dapat timbul dari ketiadaan atau ketidakjelasan pengaturan lebih lanjut di perjanjian kerja, $\mathrm{PP}$, dan PKB mengenai materi yang telah ditetapkan dalam peraturan perundangundangan.

Terbukanya peluang penerapan kekuasaan diskresi oleh hakim Pengadilan Hubungan Industrial juga tidak terlepas dari peran hakim sebagai salah satu penjaga garis depan untuk membantu mewujudkan hubungan indsustrial yang harmonis, dinamis dan berkeadilan sebagaimana dicita-citakan oleh konsepsi Hubungan Industrial Pancasila. Dengan diterapkannya kekuasaan diskresi dalam putusan-putusan perselisihan hubungan industrial, diharapkan dapat mewujudkan nilai-nilai keadilan yang lebih hakiki bagi para pihak, terutama pihak yang lebih lemah, yakni pekerja. Penggunaan kekuasaan diskresi diartikan bahwa hakim dalam mempertimbangkan dan memutus perkaranya akan memperhatikan kebijaksanaannya dan kearifannya, sehingga nilai-nilai filosofis seperti keadilan pun akan lebih diperhatikan secara maksimal.

Penerapan kekuasaan diskresi dalam lingkup pengadilan, termasuk Pengadilan Hubungan Industrial, dapat dilakukan apabila hakim-hakim yang berkedudukan di sana mempunyai pemikiran yang progresif. Dengan kata lain, hakim tersebut tidak hanya berpandangan positivisme yang semata-mata mengacu pada peraturan perundang-undangan, namun juga memperhatikan prinsip-prinsip dalam aliran hukum progresif. Hukum progresif dimulai dari asumsi dasar bahwa hukum adalah institusi yang bertujuan mengantarkan manusia kepada kehidupan yang adil, sejahtera dan menbuat manusia bahagia atau dengan perkataan lain hukum progresif merupakan hukum yang ingin melakukan pembebasan baik dalam cara berpikir maupun bertindak dalam hukum, sehingga mampu untuk membiarkan hukum itu mengalir saja untuk 
menuntaskan tugasnya mengabdi kepada manusia dan kemanusiaan. ${ }^{41}$ Hukum progresif pada hakikatnya menempatkan faktor manusia di atas peraturan perundang-undangan, sehingga nilai-nilai keadilan akan lebih diperhatikan. Penerapan kekuasaan diskresi oleh hakim Pengadilan Hubungan Industrial yang berpemikiran progresif akan mewujudkan putusan yang adil bagi pihak-pihak yang terkait. Hal ini sejalan pula dengan apa yang diamanatkan oleh Pasal 100 UU PPHI, bahwa "dalam mengambil putusan, majelis hakim mempertimbangkan hukum, perjanjian yang ada, kebiasaan dan keadilan".

\section{Penutup}

Terbuka kemungkinan bagi hakim Pengadilan Hubungan Industrial untuk menerapkan kekuasaan diskresi dalam perkara-perkara perselisihan hubungan industrial antara pekerja dan pengusaha. Kemungkinan penerapan tersebut timbul dalam perkara-perkara mengenai perselisihan kepentingan yang berupa perselisihan peningkatan syarat kerja, ataupun pada perselisihan terkait ketiadaan atau ketidakjelasan pengaturan lebih lanjut di perjanjian kerja, PP, dan PKB mengenai materi yang telah ditetapkan dalam peraturan perundangundangan. Diterapkannya kekuasaan diskresi dalam putusan-putusan perselisihan hubungan industrial tersebut diharapkan dapat mewujudkan nilai-nilai keadilan yang lebih hakiki bagi para pihak, terutama untuk melindungi pihak yang lebih lemah, yakni pekerja. Hal ini sejalan pula dengan apa yang diamanatkan oleh Pasal 100 UU PPHI, bahwa "dalam mengambil putusan, majelis hakim mempertimbangkan hukum, perjanjian yang ada, kebiasaan dan keadilan”. Namun demikian, penerapan kekuasaan diskresi di Pengadilan Hubungan Industrial hanya dapat dilakukan apabila hakim yang bersangkutan mempunyai pemikiran yang progresif.

41 Sudjito, Hukum Dalam Pelangi Kehidupan, Gadjah Mada University Press, Yogyakarta, 2012, hlm. 133. 


\section{Daftar Pustaka}

\section{Buku:}

Abdul Khakim, Pengantar Hukum Ketenagakerjaan Indonesia berdasarkan Undang-Undang Nomor 13 Tahun 2003, Citra Aditya Bhakti, Bandung, 2003.

Achmad Ali, Menguak Tabir Hukum (Suatu Kajian Filosofis dan Sosiologis, Gunung Agung, Jakarta, 2002.

Ari Hernawan, Penyelesaian Sengketa Hubungan Industrial, UII Press, Yogyakarta, 2018.

Bryan A Garner, Black's Law Dictionary Ninth Edition, Thomson Reuters, USA, 2009.

HP Rajagukguk, Peran Serta Pekerja dalam Pengelolaan Perusahaan ( $\mathrm{Co}^{-}$ Determination), Fakultas Hukum Universitas Indonesia, Jakarta, 2000.

Indroharto, Usaha Memahami Undang-Undang Tentang Peradilan Tata Usaha Negara: Buku I, Sinar Harapan, Jakarta, 1993.

John Rawls, A Theory of Justice, Massachusetts, The Belknap Press of Harvard University Press, 1971.

Lon L Fuller, Morality of Law, Yale University Press, New Haven, 1954.

M Faal, Penyaringan Perkara Pidana Oleh Polisi (Diskresi Kepolisian), Pradnya Paramita, Jakarta, 1991.

S. Prajudi Atmosudirjo, Hukum Administrasi Negara, Ghalia Indonesia, Bogor, 1994.

Subekti, Hukum Perjanjian, Intermasa, Jakarta, 2005.

Sudikno Mertokusumo, Mengenal Hukum Suatu Pengantar, Liberty, Yogyakarta, 2003.

Sudjito, Hukum Dalam Pelangi Kehidupan, Gadjah Mada University Press, Yogyakarta, 2012.

Wayne R. LaFave, The Decision To Take A Suspect Into Custody, Little Brown and Company, Boston, 1964.

Yan Pramadya Puspa, Kamus Hukum, Aneka Ilmu, Semarang, 2004.

\section{Jurnal dan Prosiding:}

Agus Budi Susilo, Makna dan Kriteria Diskresi Keputusan dan/atau Tindakan Pejabat Pemerintah Dalam Mewujudkan Tata Pemerintahan Yang Baik, Jurnal Hukum dan Peradilan No 1 Vol 42015.

Agus Nurudin, Diskresi Yudisial: Antara Keadilan dan Pencitraan, MasalahMasalah Hukum No 1 Jilid 45 Januari 2016.

Arief Sultony, Diskresi Dalam Penentuan Hasil Pemeriksaan Pajak Untuk Ditindaklanjuti Penegakan Hukum Pidana di Bidang Perpajakan, Simposium Keuangan Negara, Jakarta, 2018.

Bambang Sutiyoso, Mencari Format Ideal Keadilan Putusan dalam Peradilan, Jurnal Hukum No 2 Vol 17 April 2010.

Bayu Setiawan, Penerapan Hukum Progresif Oleh Hakim Untuk Mewujudkan Keadilan Substantif Transedensi, Kosmik Hukum No 1 Vol 18 Januari 2018.

Dina Natalia Kumampung, Tugas Fungsi dan Diskresi Hakim Untuk Mengadili dan Memutus Perkara Pidana, Lex Administratum No 2 Vol VI 2018. 
H.M. Soerya Respationo dan M Guntur Hamzah, Putusan Hakim: Menuju Rasionalitas Hukum Refleksif Dalam Penegakan Hukum, Jurnal Yustisia No 2 Vol 22013.

Khairani, Sulitnya Melaksanakan Putusan Pengadilan Hubungan Industrial (Studi Kasus Putusan Mahkamah Agung No 178 K/Pdt.Sus-PHI/2015, Prosiding Konferensi Ke-2 Perkumpulan Pengajar dan Praktisi Hukum Ketenagakerjaan Indonesia (P3HKI), Medan, Oktober 2017.

Mhd Taufiqurrahman, Kedudukan Diskresi Pejabat Pemerintahan, Jurnal Retentum No 1 Vol 1 Agustus 2019.

Ramadhita, Diskresi Hakim: Pola Penyelesaian Kasus Dispensasi Perkawinan, de Jure: Jurnal Syari'ah dan Hukum No 1 Vol 6 Juni 2014.

Togi Pangaribuan, Permasalahan Penerapan Klausula Pembatasan Pertanggungjawaban Dalam Perjanjian Terkait Hak Menuntut Ganti Kerugian Akibat Wanprestasi, Jurnal Hukum dan Pembangunan No 2 Vol 49 2019.

\section{Peraturan Perundang-Undangan:}

Undang-Undang R.I., No. 1 Tahun 1974, Perkawinan, L.N.R.I. Tahun 1974 No. 1.

Undang-Undang R.I., No. 13 Tahun 2003, Ketenagakerjaan, L.N.R.I. Tahun 2003 No. 39.

Undang-Undang R.I., No. 16 Tahun 2019, Perubahan Atas Undang-Undang Nomor 1 Tahun 1974 Tentang Perkawinan, L.N.R.I. Tahun 2019 No. 186.

Undang-Undang R.I., No. 2 Tahun 2004, Penyelesaian Perselisihan Hubungan Industrial, L.N.R.I. Tahun 2004 No. 6.

Undang-Undang R.I., No. 21 Tahun 2000, Serikat Pekerja/Serikat Buruh, L.N.R.I. Tahun 2000 No. 131.

Undang-Undang R.I., No. 30 Tahun 2014, Administrasi Pemerintahan, L.N.R.I. Tahun 2014 No. 292.

Undang-Undang R.I., No. 48 Tahun 2009, Kekuasaan Kehakiman, L.N.R.I. Tahun 2009 No. 157.

Surat Keputusan Bersama Ketua Mahkamah Agung RI Nomor 047/KMA/SKB/IV/2009 dan Ketua Komisi Yudisial RI 02/SKB/P.KY/IV/2009. 